\title{
A Comprehensive Review of Flemingia strobilifera (LAM.)
}

\section{Devlekar Shital $^{1 *}$, Khale Anubha ${ }^{2}$ and Rawal Jignyasha ${ }^{3}$}

${ }^{1}$ Pacific Academy of Higher Education and Research University, Udaipur, India

${ }^{2}$ Dean, Faculty of Sciences and Technology, SNDT Women's University, Mumbai, India

${ }^{3}$ Pacific Academy of Higher Education and Research University, Udaipur, India

*Corresponding Author: Devlekar Shital, PhD scholar, Pacific Academy of Higher

Education and Research University, Udaipur, India.
Received: April 19, 2021

Published: May 25, 2021

(C) All rights are reserved by Devlekar Shital., et al.

\begin{abstract}
The traditional systems of medicine plays a significant role in our health care system for the betterment of manhood. Flemingia strobilifera (Lam.) is used as herb in Ayurvedic medicine since ancient time. Flemingia strobilifera (Palas) belongs to the family Fabaceae, grown wildly in many parts of India. The plant is used highly by the countryside and ethnic people in curing various disorders. Flemingia strobilifera has an effective natural origin that has a tremendous future for research. The novelty and applicability of Flemingia strobilifera are hidden. Such things can be removed through modern research. The present article describes various traditional and medicinal utility of the plant and an attempt was made to gather information about the chemical composition of the plant or its species and/or its constituents.
\end{abstract}

Keywords: Flemingia strobilifera; Traditional Uses; Medicinal Uses; Phytochemistry

\section{Introduction}

Flemingia strobilifera (L.) W.t. Aiton, family Leguminosaea (Fabaceae) (Figure 1), is also known as 'Wild Hop', in Marathi: Kanfuti; commonly known as Kusrunt in Hindi; Kanphuti or Bundar in Marathi; Nallabaddu, Kannad in Telugu; Kumalu, kumbilteri in Malayalam; Makhioti in Assam; Simbusak in Bihar [1].

It grows almost throughout India, Andaman and Nicobar Islan$\mathrm{ds}$, ascending to an altitude of 4,500 ft. In Himalayas from Simla and Kumaon, mounting to $8000 \mathrm{ft}$. to Assam, Khasla, Chittagong, Siam, Malacca and Ceylon. Dehradun and Siwalik range, Bundelkhand, from Sind, Rajasthan and Bengal to South India and in Maharashtra region [1].

Ahmad, Hasan and Mahmood [2] reviewed that this is one of the antiurolithic plants from Fabaceae family.
Morphology

It is an erect shrub, 5 - $10 \mathrm{ft}$ high, with slight terete branches silky towards their tips. Leaves 3 - 4 inch long, oblong or ovate-lanceolate, acute, rounded at the base; lateral nerves 8 - 10 pairs; petioles half inch; stipules lanceolate, scarious. Racemes terminal, 3 - 6 inch long, the slender zigzag rachis rusty-pubescent; bracts 1 inch long, shortly stalked, deeply cordate, usually cuspidate at the apex. Calyx-teeth lanceolate, pilose, exceeding the tube. Corolla yellowish or greenish-white. Pod about half inch, oblong, turgid, finely downy, 2-seeded [3]. The root of Flemingia strobilifera is cylindrical or slightly tortuous. Root is earthy brownish in color its surface was fissured, rootlets and with presence of lenticels. Seeds are two, shiny and black. Flowering and fruiting time is Jan to March [4]. The flowers recemes, white or pinkish, covered by large folded bracts [5]. 


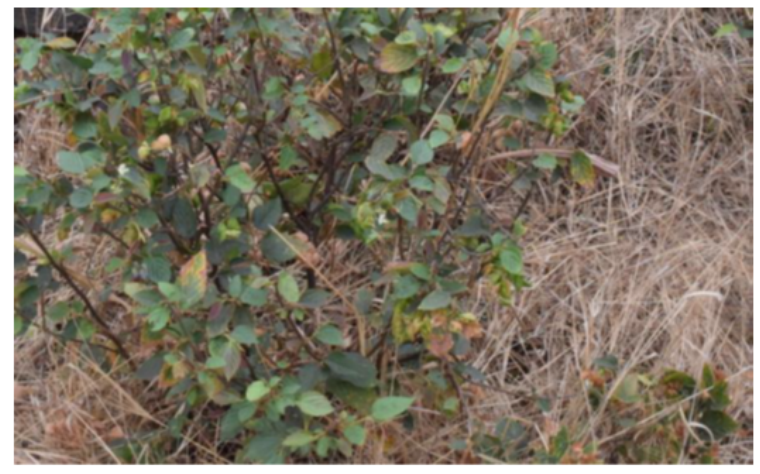

Figure 1: Flemingia strobilifera natural habitat.

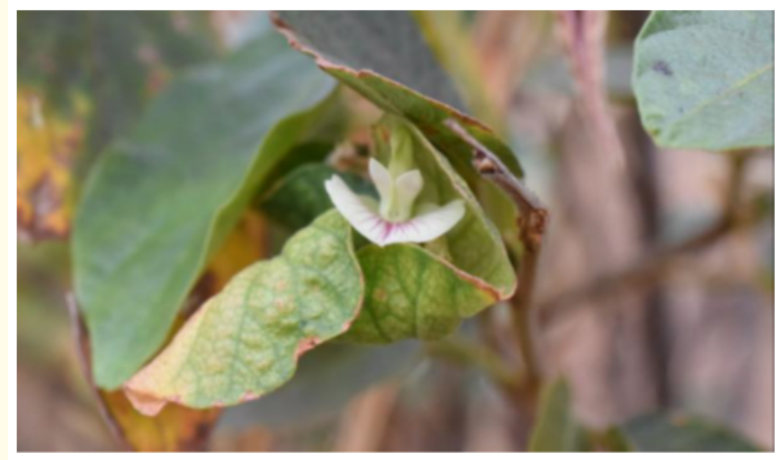

Figure 2: Flemingia strobilifera flower in natural habitat.
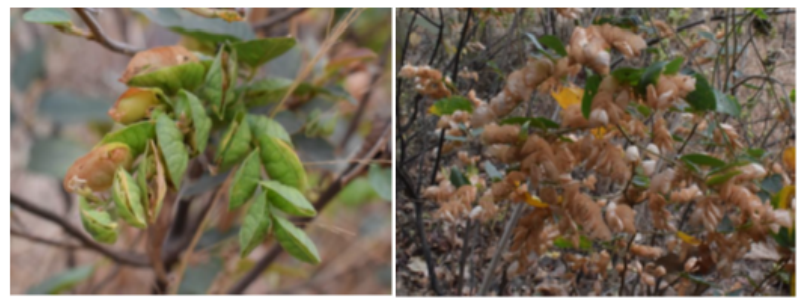

Figure 3: Flemingia strobilifera bracts (fresh and dried) in natural habitat.
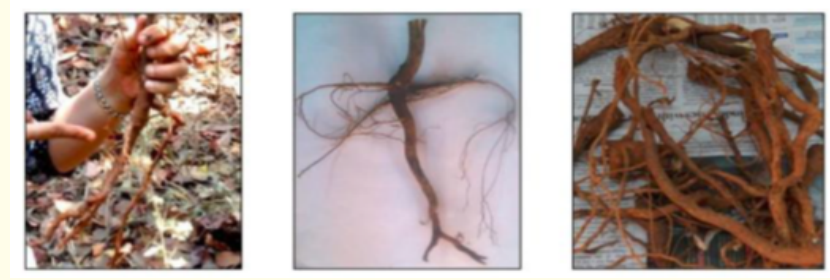

Figure 4: Flemingia strobilifera fresh roots in natural habitat and after drying.

\section{Traditional uses}

- $\quad$ Flower: The flower of Flemingia strobilifera is traditionally used as an antitubercular and used to stuff into pillows to induce sleeping at night in hyperactive children [6].

- $\quad$ Leaves: The leaves of Flemingia strobilifera is traditionally used in Java as vermifuge for children [7]. In the Philippines a decoction/infusion of the leaves and flowers is prescribed by "curanderose" against tuberculosis [8]. Arabians use it in cosmetics, as anthelmintic and as a remedy for coughs and cold [3,9]. In Malaysia, fever is contained by bathing the patient with a decoction of the leaves [10]. Pizon., et al. reviewed that Subanen Tribe used leaves for treatment to reduce internal inflammation, Mayoma, cancer and cough [11].

- Stem: The stem bark is traditionally used to treat inflammatory diseases. In Nepals the juice of the bark is given in the dose of four teaspoons twice daily [12].

- $\quad$ Root: It is reported that roots of F. strobilifera are used by Santals in epilepsy, insomnia, hysteria and to relieve pain [7-14]. In Burma the roots of Flemingia strobilifera are used to treat epilepsy [8]. The Assamese take a small portion of the root of Flemingia strobilifera in order to induce sleep and it is said, in case of severe pain heavy sleep is brought on according to the amount of root taken, without ill effects [15]. In India, root paste applied externally to body swellings. In Nepal, Root juice (fresh roots crushed in cup of water) is taken for treating diarrhea and dysentery. In Trinidad and Tobago, it is used for kidney problems [16]. Pizon., et al. reviewed that Subanen Tribe used roots for treatment of 
cough, diabetes, cancer and tuberculosis [11]. Root decoction is given in menstrual irregularities [27].

- Tuber: Tikdar., et al. profiles that tuber paste taken orally to cure from dysentery [18].

\section{Medicinal uses}

Medicinal plants certainly have countless importance to human health in the treatment of variety of diseases [11].

- Flowers: Taqueer and Itankar evaluated anti-inflammatory activity of aerial of plant using methanolic and hydro alcoholic extracts [19].

- Seeds: Shreedevi and Patel mentioned the use of seed as an oral contraceptive [20].

- Leaves: Anil, Dora, Gahlot and Tripathi studied anthelmintic activity of methanolic extract of leaves [21]. Madan., et al. mentioned that decoction of Flemingia strobilifera leaves are used as a health tonic by rubbing it on the body [1]. Pizon., et al. studied in vitro antioxidant activity of $80 \%$ hydromethanolic and aqueous extract of leaves [22]. Quevedo., et al. studied effect of ethanolic extract of leaf on blood cholesterol level [23]. Anil Kumar., et al. studied Hepatoprotective effect of Chloroform extract of leaf on paracetamol induced hepatotoxicity [24]. Ramachandran, Clement and Maxwell studied cytotoxic effect of petroleum and chloroform extract of leaves [25]. Taqueer and Itankar evaluated anti-inflammatory activity of aerial of plant using methanolic and hydro alcoholic extracts [19].

- Roots: Nemkul, Bajracharya and Shrestha reported in vitro antimicrobial activity of roots using Hexane and 70\% Methanol extract using GC-MS technique [26]. Soe, Thein and Oo evaluated wound healing property using $70 \%$ ethanolic root extract [27]. Kavita G, Vijay KL, Shivesh J studied anticonvulsant activity of ethanol extract of root [28]. Thakur., et al. studied anxiolytic effect of aqueous extract of root [29]. Anil kumar KV studied anti ulcerogenic property of chloroform extract of root [30]. Chen., et al. 1991 studied antioxidant activity of methanolic extract of root of Flemingia philippinensis [31]. Madan., et al. (2010) studied antioxidant activity of methanolic and butanolic roots extracts [32]. Hsieh., et al. studied antioxidant activity of aqueous extract of root [33]. Madan., et al. studied antimicrobial activity of methanol, bu- tanol and dichloromethane extract of root [34]. Mahato and Chaudhari evaluated antibacterial activity of methanolic extract of leaves [35].

- Stems: Taqueer and Itankar evaluated anti-inflammatory activity of aerial of plant using methanolic and hydro alcoholic extracts [19].

\section{Phytochemistry}

Gahlot, Lal and Jha studied extracts of ethanolic extracts of root for phytochemical screening for presence of total phenolics content which possess Antioxidant activity [36]. Nemkul, Bajaracharya and Shrestha studied extracts of Hexane and aqueous methanolic extracts of root which shows the presence of polyphenols and terpenoids with Antimicrobial activity [26]. Jeong., et al. evaluated phytoestrogen for estrogenic effect [37]. Shailajan and Mascarenhas evaluated Kaempferol from ethanolic extracts of aerial parts Flemingia tuberosa with roots showing maximum content of Kaempferol [38]. Madan, Gullaiya, Singh and Kumar performed review of previous chemical studies which showed that flavonoids, flavonoid glycosides, chalcones, epoxychromenes and pterocarpans are main constituents found in Strobilifera species [1]. Pizon, Nuneza, Mylene and Senarath studies aqueous and hydromethanolic extracts of leaf for total phenolics content and studied Antioxidant property of the leaves [22]. Hua, Zhai, and Zhongdong performed review on different classes of compounds present in genus Flemingia Roxb which states the presence of main groups: flavones, triterpenes accompanied with sterols and anthraquinones [39]. Pizon antin, Nuneza, Uy and Senaratha studied aqueous and 80\% methanolic extract of leaf of Flemingia strobilifera for determination of total phenolic content; where aqueous extract shows high phenolic content in comparison of hydromethanolic extract; however, hydromethanolic extract exhibited high antioxidant activity [22]. Mahajon B, Remadevi R, Sunil Kumar KN, Ravishankar B performed preliminary analysis of root of Flemingia strobilifera which showed presence of carbohydrate, cumarins, flavonoids, phenols, quinine, saponins, tannins and terpenoid [40]. Mascarenhas, Shailajan and Menon studied antioxidant and Hepatoprotective activity of ethanolic extracts of aerial parts of Flemingia tuberosa using Kaempferol as a phytomarker [41]. Madan, Singh, Kumar, Kohli, Mir and Ahmad isolated Flavanone, Genistin and $\beta$ - sitosterol-D glucoside from methanol, butanol and dichloromethane root extracts of Flemingia strobilifera [34]. Gahlot, Lal and Zha studied total phenolic 
content considering per mg of Gallic acid equivalent and Flavonoid content per mg of Quercetin equivalent with in vitro antioxidant activities of Flemingia species (chappar, macrophylla, strobilifera) [36]. Shailajan and Mascarenhas studied data on sensitivity and linearity for phytomarkers to determine content of some major groups of phytochemical constituents such as Quercetine for total flavonoid, Gallic acid for total phenolics, bismuth nitrate pentahydrate for total alkaloids, Diosgenin for total saponins and Linaliol for total terpenoids in Flemingia tuberosa [38]. Gahlot, Jha and Lal performed pharmacognostical standardization of root of Flemingia chappar for presence of steroids, flavonoids, tannins and carbohydrates [5]. Lai, Tsui., et al. studies methanolic extract of root of Flemingia macrophylla for identification of phytoconstituents such as genistine, $\beta$ - sitosterol, stigmasterol etc. [42].

\section{Conclusion}

Since ancient time, plants are being used as remedies for various ailments. Herbs are natural remedies used to get physiological functions normal which are affected by diseases. It is very essential to have a proper research work of medicinal plants and to know their probable impacts for the improvement of health and hygiene through an eco- friendly system. Now days interest in research of photoactive from plants sources is increasing because of their versatile health benefits. Findings obtained from such research may lead to validation of traditionally used medicinal plants since ancient time, plants are being used as remedies for various ailments. Herbs are natural remedies used to get physiological functions normal which are affected by diseases. It is very essential to have a proper research work of medicinal plants and to know their probable impacts for the improvement of health and hygiene through an ecofriendly system. Now days interest in research of phytoactives from plants sources is increasing because of their versatile health benefits. Findings obtained from such research may lead to validation of traditionally used medicinal plants full usage of these plants.

The present review reveals that the plant Flemingia strobilifera is used in treating various ailments. A detailed research work in the characterization and standardization is strongly required for this potential plant in developing its various formulations in combination with other useful plants which can be valuable for human and animal wellbeing. This comprehensive review will be used to explore much depth about this plant known by the name "Wild Hop".

\section{Conflict of Interest}

The authors declare no conflict of interest.

\section{Bibliography}

1. Madan S., et al. "Flemingia strobilifera: Review on Phytochemistry and Pharmacological Aspects". International Journal of Pharmaceutical Sciences and Research 4.4 (2013): 252-262.

2. Ahmad Hasan and Mahmood. "Decomposition and nutrient release pattern of three agroforestry shrub species foliage at Dello-Menna district of Bale zone". 8 (2017): 23.

3. Duthie JS., et al. "Flora of the upper gangetic plain". New Connaught place, Dehradoon. 1 (1994): 215-220.

4. Gahlot K., et al. "Comparative morpho-anatomical and Preliminary Phytochemical studies of Flemingia strobilifera (L.) R.Br and Flemingia macrophylla (Willd) Merr (Fabaceae)". International Journal of Pharm Tech Research 4.1 (2012): 495-500.

5. Gahlot K., et al. "Pharmacognostical Standardization of roots of Flemingia chappar Benth". Journal of Pharmaceutical Sciences and Research 3.4 (2011): 1190-1194.

6. https://www.globinmed.com

7. Anonymous. "The Wealth of India, Raw Materials, Publication and Information Directorate, CSSIR, New Delhi". 4 (1993): 4548.

8. http://uvp.blogspot.com/2006.05/flemingia

9. Kirtikar KR and Basu BD. "Indian Medicinal Plants". Allahabad, India: Lalit Mohan Basu Publishers 1 (1935): 813.

10. Johnson T. “CRC ethnobotany desk reference CRC Press Boca Raton”. (1999): 352.

11. Pizon JR., et al. "Ethnobotany of Medicinal Plants Used by the Subanen Tribe of Lapuyan, zamboanga del Sur". Bulletin of Environment, Pharmacology and Life Sciences 5.5 (2016): 53-67.

12. Manandhar NP and Manandhar S. "Plants and people of Nepal Timber Press Portland”. (2002): 237.

13. Nadkarni KM. Dr. K. M. Nadkarni's Indian materia medica: Repr, Volume 1 Popular Prakashan Pvt. Ltd Mumbai 1. (1976): 556. 
14. Singh V and Jain DK. "Taxonomy of Angiosperms Rastogi Publication New Delhi". (2005): 255.

15. Kirtikar KR and Basu BD. "Indian Medicinal Plants”. 1 (1993): 814-815.

16. http://www.stuartxchange.org/panapanarah an/payang-payang.html

17. Gogoi and Zaman. "Phytochemical Constituents of Some Medicinal Plant Species Used in Recipe During 'Bohag Bihu' in Assam". Journal of Pharmacognosy and Phytochemistry 2.2 (2013): 30-40.

18. Tikdar P., et al. "Phytochemical analysis of medicinal plants used for treatment of dysentery and diarrhoea by the Paraja Tribe of Koraput, Odisha, India". 5.2 (2017): 01-04.

19. Taqueer $M$ and Itankar PR. "Evaluation of Anti-inflammatory Activity of Flemingia strobilifera linn. Fabaceae". Research Journal of Pharmacy and Technology 2.4 (2009): 865-867.

20. Shreedevi P and Patel BR. "Ethnomedicinal Uses Of Flemingia strobilifera (L).W.T.AITON". International Journal of Pharmaceutical and Biological Science 6 (2018): 1-5.

21. Anil K., et al. "Anthelmintic Activity of Flemingia strobilifera (R.Br)". International Journal of Research in Pharmaceutical and Biomedical Sciences 2.3 (2011): 1077-78.

22. Pizon JR., et al. "GC-MS analysis and evaluation of in vitro antioxidant potential and total phenolics content of wild hops (Flemingia strobilifera (L.) W. T. Aiton)". 8 (2016): 25-32.

23. Quevedo K., et al. "Effect of Flemingia strobilifera Linn. (Payangpayang) extract on blood cholesterol levels of albino mice". 14 (2015): 37-43.

24. Anil Kumar AV., et al. "Hepatoprotective effect of Flemingia strobilifera R.Br. on paracetamol induced hepatotoxicity in rats". International Journal of PharmTech Research 2.3 (2010): 1924-1931.

25. Ramachandran G., et al. "Cytotoxic activity of selected West Indian medicinal plants against a human leukaemia cell line". West Indian Medical Journal 59.6 (2010): 597-601.
26. Nemkul CM., et al. "Phytochemical Evaluation and In Vitro Antimicrobial Activity of the Roots of Flemingia strobilifera (L.) R. Br". 17 (2019): 98-103.

27. Soe SZ., et al. "Evaluation on wound healing properties of root extract of Flemingia strobilifera (L.) R. BR. in albino rat model". Journal of Basic and Clinical Pharmacy 17 (2019): 181-188.

28. Kavita G., et al. "Anticonvulsant potential of ethanol extracts and their solvent partitioned fractions from Flemingia strobilifera root". Pharmaceutical Research 5.4 (2013): 265-270.

29. Thakur S., et al. "Anxiolytic effect of root extract of amazing folklore herb Flemingia strobilifera (L.)w.T.ation in albino mice". International Journal of Current Research 9.11 (2017): 4.

30. Anil Kumar KV., et al. "Evaluation of anti-ulcerogenic properties from the root of Flemingia strobilifera". Journal of Basic and Clinical Pharmacy 2.1 (2011): 33-39.

31. Chen M., et al. "Two isoflavones from Flemingia philippinensis". Phytochemistry 30 (1991): 3842-3844.

32. Madan S., et al. "Phytochemical analysis and free-radical scavenging activity of Flemingia strobilifera (Linn) R. Br". 1.4 (2010): 183-190.

33. Hsieh PC., et al. "Activities of antioxidants, $\alpha$-Glucosidase inhibitors and aldose reductase inhibitors of the aqueous extracts of four Flemingia species in Taiwan". Botanical Studies 51 (2010): 293-302.

34. Madan S., et al. "A New Flavanone from Flemingia strobilifera (Linn)R. Br. and its Antimicrobial Activity". Tropical Journal of Pharmaceutical Research 7.1 (2008): 921-927.

35. Mahato RB and Chaudhary RP. "Ethnomedicinal study and antibacterial activities of selected plants of Palpa district, Nepal". Scientific World 3.3 (2005): 26-31.

36. Gahlot K., et al. "Total Phenolic content, flavonoid content and In vitro antioxidant activities of Flemingia species (Flemingia chappar, Flemingia macrophylla and Flemingia strobilifera)". Research Journal of Pharmacy and Technology 6.5 (2013): 516523.

37. Jeong Si-Yeon., et al. "Estrogenic effects of phytoestrogens derived from Flemingia strobilifera in MCF-7 cells and immature 
rats". Archives of Pharmacal Research 41.5 (2018): 519-529.

38. Shailajan S and Mascarenhas R0. "Phytochemical and Chromatographic Evaluation of Kaempferol from Flemingia tuberosa Dalzell: An Endemic Plant of Western Ghats". 6.6 (2018): 051-057.

39. Hua Li., et al. "Chemical Constituents and Bioactivities of the Plants of Genus Flemingia Roxb. et Ait. (Leguminosae)". Combinatorial Chemistry and High Throughput Screening 15 (2012): 611-622.

40. Mahajon B., et al. "Preliminary Analysis of Botanical and Phytochemical Features of Kamalu -Root of Flemingia strobilifera". 3.4 (2014): 1-6.

41. Mascarenhas R., et al. "Antioxidant and Hepatoprotective activity of Flemingia tuberosa Dalzell in $\mathrm{CCl} 4$-induced hepatotoxicity in rats". 10.6 (2020): 032-038.

42. Lai WC., et al. "Phyto-SERM Constitutes from Flemingia macrophylla". International Journal of Molecular Sciences 14.8 (2013): 15578-15594.

Volume 5 Issue 6 June 2021 (C) All rights are reserved by Devlekar Shital., et al. 